\title{
PENGARUH KEMAMPUAN MEMBACA, KEMAMPUAN BERFIKIR KRITIS DAN KEDISPLINAN BELAJAR TERHADAP KEMANDIRIAN BELAJAR SISWA SMPN 3 PERBAUNGAN
}

\author{
Muhammad Restu Fauzi* \\ *Mahasiswa Magister Pendidikan Agama Islam \\ Universitas Islam Negeri Sumatera Utara
}

\begin{abstract}
This study aims to determine (1) the relationship of reading ability to student learning independence (2) the relationship of the ability to think critically towards the independence of student learning (3) the discipline of learning to the independence of student learning (4) the influence of reading skills, and the ability to think critically, and towards Student learning independence (5) Effect of reading ability, and learning discipline on student learning independence (6) Effect of critical thinking skills, and learning discipline on student learning independence (7) Effect of reading ability, critical thinking skills, and learning discipline on student learning independence.The results of the study: 1) There is a Positive and Significant Relationship in the Ability to Read Against Learning Independence Students who proved the correlation is worth 0.761. 2) There is a Positive and Significant Relationship to the Critical Thinking Ability of Students' Learning Independence which is worth 0.883. 3) There is a Positive and Significant Relationship in Learning Discipline Against Student Learning Independence, with a value of 0.938 Multiple linear regression obtained by regression equation, $\mathrm{Y}=15.238+0.352 \mathrm{X} 1+$ $0.623 \times 2+$ e. 5) There is a positive and significant influence between reading ability $(X 1)$, and learning discipline $(X 3)$ on student learning independence $(\mathrm{Y})$, the results of the calculation of multiple linear regression analysis obtained regression equation that is $\mathrm{Y}=12.865+$ $0.224 \mathrm{X} 1+0.720 \mathrm{X} 2+\mathrm{e} .6)$ There is a Positive and Significant Influence Between Critical Thinking Ability (X2) and Learning Discipline (X3) on Student Learning Independence $(\mathrm{Y})$. Multiple linear regression analysis obtained regression equation, namely $Y=15.671+0.312 \mathrm{X} 1+0.594 \mathrm{X} 2+\mathrm{e}$. 7) There is a Positive and Significant Influence Between Reading Ability (X1), Critical Thinking Ability (X2) and Learning Discipline (X3) Against Student Learning Independence $(\mathrm{Y})$ which is proven through the results of the calculation of multiple linear regression analysis obtained the regression equation that is $\mathrm{Y}=11.302+0.173 \mathrm{X} 1+0,276 \mathrm{X} 2+0.524 \mathrm{X} 3+\mathrm{e}$. Results of hypothesis analysis Simultaneously, fcount> ftabel where 237.611> 2.77. And the results of the analysis of the coefficient of
\end{abstract}


determination in this study is the $\mathrm{R}$ Square value of 0.963 . And with a significance level of $5 \%$.

\section{Keyword : Reading Ability, Critical Thinking Ability And Disciplination Learning}

\section{PENDAHULUAN}

Pendidikan merupakan hal sangat penting bagi kehidupan masyarakat berbangsa dan bernegara. Melalui pendidikan seseorang akan mendapatkan ilmu yang bermanfaat bagi kehidupan, apalagi pada era globalisasi yang menuntut kesiapan bangsa untuk barsaing secara bebas. Pendidikan merupakan salah satu faktor pentingmerupakan salah satu modal utama bagi terciptanya bangsa yang berkualiatas. Dalam mewujudkan tingkat pendidikan yang berkualitas, pemerintah selalu melakukan upaya perbaikan dan inovasi pendidikan salah satunya dengan perbaikan kurikulum. Kurikulum terbaru yang di tetapkan pemerintah adalah kurikulum 2013.

Salah satu lembaga pendidikan yang menerapkan Kurikulum 2013 dalam kegiatan belajar mengajar adalah SMP Negeri 3 Perbaungan. Sesuai dengan tujuan Kurikulum 2013, sekolah yang menggunakan Kurikulum tersebut akan menghasilkan siswa yang kreatif dan mandiri dalam belajar. Tirtarahardja dan Sulo (2008: 50) menjelaskan kemandirian dalam belajar diartikan sebagai "aktivitas belajar yang berlangsungnya lebih didorong oleh kemauan sendiri, pilihan sendiri, dan tanggung jawab sendiri dari pembelajaran". Hal itu berarti bahwa melalui kemandirian belajar siswa diharapkan mampu bertanggung jawab atas dirinya dalam kegiatan belajar.Namun pada kenyataannya berdasarkan observasi dan wawancara yang peneliti lakukan pada tanggal 20 september 2017 dengan Guru Pendidikan Agama Islam, kemandirian belajar siswa masih rendah yang terlihat selama kegiatan belajar mengajar berlangsung. Di SMP Negeri 3 Perbaungan siswa masih pasif dan tidak mandiri dlam belajar. Tidak terdapat interaksi timbal balik antara siswa dengan guru. Siswa lebih banyak berpatokan pada guru sebagai sumber belajarnya dan siswa kurang kreatif dalam mencari informasi dan sumber belajar lain, pada saat kegiatan belajar mengajar berlangsung siswa banyak yang pasif dalam belajar dan tidak mengikuti pelajaran dengan baik, banyak siswa yang bermain-main ketika kegiatan belajar berlangsung. Pada saat diadakan ujian atau ulangan hasil jawaban siswa atas pertanyaan atau ujian dari guru memiliki nialai yang masih dibawah standar ketuntasan minimum siswa masih cenderung menjawab dengan kata-kata atau pendapat dari 
buku teks bukan hasil pemikirannya sendiri sehingga guru sulit untuk menilai kemandirian siswa.

Kemandirian belajar siswa, merupakan faktor yang berasal dari dalam diri siswa disebut juga faktor intrinsik. Kemandirian belajar dapat ditingkatkan melalui beberapa faktor yang berasal dari dalam diri siswa seperti motivasi, kemampuan membaca, kemampuan berfikir kritis dan kedispilinan dalam belajar.Menurut Tarigan (2005:9) “Tujuan utama dalam membaca adalah untuk mencari serta memperoleh informansi, mencakup isi, memahami makna bacaan, makna arti (meaning) erat sekali berhubungan dengan maksud tujuan, atau intensif kita dalam membaca".

Berdasarkan pengertian tersebut diketahui kemampuan membaca merupakan keterampilan yang dapat memperkaya pengetahuan dan meningkatkan daya nalar. Dengan membaca seseorang akan memperoleh informasi penting tentang hal-hal baru yang dibacanya. Selain faktor kemapuan membaca, kemampuan berfikir kritis juga mempengaruhi kegiatan belajar mengajar. Menurut Surya (2015 : 117) “Berfikir adalah proses yang melibatkan operasi mental seperti induksi, deduksi, dan klasifikasi dan penalaran". Sedangkan berfikir kritis merupakan suatu proses intelektual dalam pembuatan konsep, mengaplikasikan, menganalisis, mensintesis, dan mengevaluasi berbagai informasi yang didapat dari hasil observasi, pengalaman, refleksi dimana hasil dari proses ini digunakan sebagai dasar mengambil tindakan. Kemampuan berfikir kritis memerlukan kemampuan mengingat dan memahami.Faktor lain yang harus diperhatikan adalah kedisiplinan belajar. Menurut Slameto (2010 : 67) “Disiplin belajar merupakan salah satu faktor dari dalam diri siswa yang dapat mempengaruhi akademisnya. Agar siswa belajar lebih maju, siswa harus disiplin baik disekolah, dirumah dan di perpustakaan”. Selanjutnya Sofan (2013 : 162) “Kedisplinan merupakan sikap seseorang yang menunjukkan ketaatan atau kepatuhan terhadap peraturan dan tata tertib yang telah ada dan dilakukan dengan senang hati dan kesadaran diri".

\section{METODOLOGI PENELITIAN}

Dalam Penelitian ini jenis penelitian yang dilakukan merupakan penelitian kuantitatif korelasional menggunakan teknik atau model ekxpost facto. Populasi dalam penelitian ini adalah jumlah seluruh siswa kelas IX yang terdiri dari tujuh kelas yang berjumlah 215 orang dan sampel sebanyak 60 orang yang di ambil secara proportional stratified random sampling. Instrumen yang digunakan adalah skala model Likert. 
Untuk mengetahui hubungan antara variabel bebas dengan variabel terikat, maka data dianalisis dengan regresi sederhana dan regresi ganda. Analisis dibantu dengan menggunakan program SPSS versi 20.0.

\section{HASIL PENELITIAN DAN PEMBAHASAN}

Hasil analisis data penelitian melalui perhitungan uji korelasi untuk melihat hubungan antar variabel. Menunjukkan hubungan yang sangat kuat, signifikan dan searah antara kemampuan membaca terhadap kemandirian belajar yang bernilai 0,761 dengan angka signifikansi sebesar 0 . Hal ini dapat diakibatkan karena dengan adanya kemampuan membaca yang baik maka siswa akan mudah memahami pelajaran terutama dalam memahami isi buku pelajaran PAI yang diajarkan guru. Jika siswa memiliki kemampuan membaca yang tinggi baik dari segi kecepatan maupun ketepatan maka siswa tersebut juga akan mudah dalam memahami isi bacaan yang di bacanya sehingga siswa dapat dengan mudah memahami pelajaran tanpa harus berpatokan kepada guru. Sesuai pendapat Davis dalam buku Analisis Kesalahan karya Pateda (1989:93) menyebutkan "membaca pemahaman akan mengukur kemampuan membaca seseorang, yakni mencari serta memperoleh informasi, mencakup isi, memahami makna bacaan, makna arti (meaning)". Untuk mencapai tingkat membaca pemahaman yang tinggi ada kriteria yang harus dipenuhi diungkapkan dalam Penelitian yang dilakukan Baldridge (1987) dalam Harjasujana menjelaskan bahwa setiap orang dituntut untuk membaca tidak kurang dari 840.000 kata per minggu. Jika Kecepatan Efektif Membaca (KEM) yang mereka miliki hanya 250 kata per menit, waktu yang harus mereka gunakan khusus untuk membaca saja adalah 8 jam per hari. Kalaupun waktu yang tersedia hanya 4 jam per hari, maka kecepatam membaca mereka harus dilipatgandakan menjadi $500 \mathrm{kpm}$. Jika kriteria dalam membaca telah dikuasai siswa maka dengan sendirinya kemandirian belajar siswa juga akan mengalami peningkatan karena dengan kemampuan membaca yang baik maka siswa akan semakin mandiri dalam belajarnya, siswa tidak hanya mengharapkan informasi hanya dari guru saja tetapi juga menggali informasi dari apa yang dibacanya.

Hasil analisis data penelitian melalui perhitungan uji korelasi untuk melihat hubungan antar variabel. Menunjukkan hubungan yang sangat kuat, signifikan dan searah antara kemampuan berfikir kritis terhadap kemandirian belajar yang bernilai0,883 dengan angka signifikansi sebesar 0 . Selanjutnya juga dilakukan pengujian hipotesis 
secara parsial variabel $\mathrm{X}_{2}$ diketahui bahwa $\mathrm{t}_{\text {hitung }}>\mathrm{t}_{\text {tabel }}$ dimana 4.553 $>2.003$ yang berarti ada pengaruh signifikan antara kemampuan berfikir kritis terhadap kemandirian belajar PAI siswa. Hasil ini dapat terjadi karena kemampuan berfikir kritis merupakan salah satu faktor penting yang berasal dari dalam diri siswa. Dengan adanya kemmapuan berfikir kritis yang tinggi siswa akan dengan cepat dan mudah dalam belajar walaupun kegiatan belajar mengajar sulit untuk diselesaikan, namun siswa dapat menyelesaikannya dengan mudah jika dengan kemampuan berfikir kritis. Kemampaun berfikir kritis sendiri menurut Surya (2015 : 123), “Berfikir kritis lebih bersifat kekiri dengan fokus pada menganalisis dan mengembangkan berbagai kemungkinan. Berfikir kritis yaitu berfikir untuk: (1) membandingkan dan mempertentangkan berbagai gagasan; (2) memperbaiki dan memperhalus; (3) bertanya dan verifikasi; (4) menyaring, memilih dan mendukung gagasan; (5) membuat keputusan dan timbangan; (6) menyediakan landasan untuk suatu tindakan".

Dari pengertian tersebut kita dapat mengetahui dalam berfikir kritis banyak hal yang harus dilalui mulai dari point pertama hingga point ke 6, akan tetapi jika siswa mampu berfikir kritis maka siswa juga akan mampu mandiri dalam belajarnya. Sejalan dengan hasil penelitian samuel Tri Susetyo Parwoto (2013) dalam jurnal universitas universitas negeri Yogyakarta yang berjudul Pengaruh kemampuan berpikir, gaya belajar dan kemampuan adaptasi terhadap kemandirian belajar Siswa SMK N 3 yogyakarta yang menunjukkan bahwa "(1) kemampuan berpikir kritis siswa termasuk dalam kategori sedang yaitu 85,00\%, (2) gaya belajar siswa termasuk dalam kategori sedang yaitu 85,00\% dan sebesar 52,50\% siswa memiliki gaya belajar visual, (3) kemampuan adaptasi siswa termasuk dalam kategori sedang yaitu $76,25 \%$, (4) kemandirian belajar siswa termasuk dalam kategori sedang yaitu $83,75 \%$, (5) terdapat pengaruh kemampuan berpikir kritis sebesar $45,8 \%$ terhadap kemandirian belajar, (6) terdapat pengaruh gaya belajar sebesar $24,7 \%$ terhadap kemandirian belajar, (7) terdapat pengaruh kemampuan adaptasi sebesar 48,3\% terhadap kemandirian belajar, dan (8) terdapat pengaruh dari kemampuan berpikir kritis, gaya belajar dan kemampuan adaptasi secara simultan sebesar 53,6\% terhadap kemandirian belajar". Hasil penelitian terdahulu memiliki perbedaan pada hasil perhitungan yang menunjukkan bahwa kemampuan berfikir kritis mempengaruhi kemandirian hanya sepertiga persen saja sedangkan hasil penelitian yang penulis lakukan memperoleh hasil yang lebih besar. 
Berdasarkan hasil analisis dapat disimpulkan bahwa terdapat hubungan dan pengaruh yang positif dan signifikan antara kemampuan berfikir kritis $\left(X_{2}\right)$ terhadap kemandirian belajar siswa. Dengan demikian dapat dikatakan bahwa semakin tinggi berfikir kritismaka semakin tinggi pula kemandirian belajar.

Hasil analisis data penelitian melalui perhitungan uji korelasi untuk melihat hubungan antar variabel. Menunjukkan hubungan yang sangat kuat, signifikan dan searah antara kedisiplinan belajar terhadap kemandirian belajar dengan nilai 0,938 dengan angka signifikansi sebesar 0 . Kemudian perhitungan uji $t$ (parsial) variabel $X_{3}$ diketahui bahwa $t_{\text {hitung }}>t_{\text {tabel }}$ dimana $8.353>2.003$ yang berarti kedisiplinan belajar terhadap kemandirian belajar siswa.

Hal ini disebabkan oleh faktor kedisiplinan belajar yang memiliki andil besar dalam kegiatan belajar terutama dalam hal kepatuhan dan tanggungjawab yang berasal dari dalam diri siswa dan juga motivasi serta tekanan dari guru, nanang Martono ( 2014: 104) yang mengemukakan bahwa "kedisiplinan harus dilakukan secara berkelanjutan melalui pelatihan, pembiasaan, dan pengulangan secara rutin agar dapat membentuk sikap atau cara hidup bagi siswa yang dapat dimulai dari disiplin sekolah yang membutuhkan kesadaran diri dan evaluasi dalam diri siswa". Jika siswa sudah mampu menanamkan disiplin dalam dirinya maka siswa akan mampu melaksanakan kegitan belajar mengajar dengan baik dan optimal.

Berdasarkan penelitian yang dilakukan yusni harahap tentang pengaruh motivasi belajar dan disiplin belajar terhadap prestasi belajar alquran hadis kelas x man binjai TA. 2015-2016 menyimpulkan bahwa 1) Terdapat pengaruh positif dan signifikan antara Motivasi Belajar terhadap Prestasi Belajar Alquran Hadīs Kelas X MAN Binjai TA. 2015-2016, dibuktikan dengan diperoleh harga koefisien korelasi hitung $r$ sebesar 0,871, dan tabel $r$ sebesar 0,233 artinya hitung $r>r$ tabel. uji hitung $t$ sebesar 14,837 lebih besar dari tabel $t$ sebesar 2,65, (2) Terdapat pengaruh positif dan signifikan antara Disiplin Belajar terhadap Prestasi Belajar Alquran Hadīs Siswa Kelas X Madrasah Aliyah Negeri Binjai Tahun Ajaran 20152016, dibuktikan melalui analisis regresi sederhana diperoleh harga koefisien korelasi hitung $r$ sebesar 0,7185 dan tabel $r$ sebesar 0,233 artinya hitung $r>$ rtabel, dengan taraf signifikansi 5\%, (3) Terdapat pengaruh positif dan signifikan antara Motivasi Belajar dan Disiplin Belajar terhadap Prestasi Belajar Alquran Hadīs Siswa Kelas X Madrasah Aliyah Negeri Binjai TA. 2015-2016 secara bersama-sama, hasil temuan ini 
semakin memperkuat hasil penelitian yang peneliti lakukan karena hasil penelitian relevan menunjukkan kesesuaian dengan hipotesis dalam penelitian yang penulis lakuakan.

Berdasarkan hasil analisis dapat disimpulkan bahwa terdapat hubungan dan pengaruh yang positif dan signifikan antara kedisiplinan belajar $\left(X_{3}\right)$ terhadap kemandirian belajar siswa. Dengan demikian dapat dikatakan bahwa semakin tinggi kedisiplinan belajar maka semakin tinggi pula kemandirian belajar PAI siswa kelas IX SMP Negeri 3 Perbaungan.

Hasil analisis data penelitian melalui perhitungan uji regresi untuk melihat Pengaruh kemampuan membaca dan kemampuan berfikir kritis terhadap kemandirian belajar PAI siswa yang memiliki Hasil perhitungan analisis regresi linear berganda didapatkan persamaan regresi yaitu $\mathrm{Y}=$ $15.238+0,352 X 1+0,623 X 2+$ e. Persamaan bermaknaJika variabel kemampuan membaca $\left(X_{1}\right)$, dan kemampuan berfikir $\operatorname{kritis}\left(X_{2}\right)$ bernilai nol, maka kemandirian belajar PAI siswa ( $Y$ ) akan tetap sebesar15.238. Selanjutnya Jika variabel kemampuan membaca $\left(X_{1}\right)$ Meningkat 1 (satu) persen sementara variabel kemampuan berfikir kritis $\left(X_{2}\right)$ di anggap tetap maka kemandirian belajar PAI siswa ( Y) akanmeningkat sebesar 0,352 persen. Dan Jika variabel kemampuan berfikir kritis $\left(X_{2}\right)$ Meningkat 1 (satu) persen sementara kemampuan membaca $\left(X_{1}\right)$ di anggap tetap, maka kemandirian belajar PAI siswa (Y) akan meningkat sebesar 0,623 persen.Kedua koefisien bernilai positif yang menyatakan bahwa ada pengaruh positif antara pengaruh kemampuan membaca $\left(X_{1}\right)$, dan kemampuan berfikir kritis $\left(\mathrm{X}_{2}\right)$ terhadap kemandirian belajar PAI siswa (Y) kelas IX SMP Negeri 3 Perbaungan. Berdasarkan penjabaran tersebut dapat dijelaskan bawa jika variabel-variabel bebas $\left(\mathrm{X}_{1}, \mathrm{X}_{2}\right)$ meningkat maka akan mempengaruhi peningkatan variabel terikat $Y$.

Penjelasan tersebut menunjukkan adanya pengaruh antara kemampuan membaca dan kemampuan berfikir kritis. Hasil penelitian ini sejalan dengan hasil penelitian sebelumnya yang dilakukan oleh Arief Muttaqiin dan Wahyu Sopandi dalam jurnal ilmu pendidikan dan pengajaran, vol. 2 no. 2, juli 2015 yang menyatakan bahwa "terdapat hubungan yang signifikan antara kemampuan membaca kritis dengan kemampuan berpikir kritis siswa pada $a=0,05$ (sig. 0,047), namun hubungan tersebut berada pada kategori rendah $(\mathrm{r}=0,339)$. Dengan demikian, kamampuan membaca kritis perlu dilatihkan atau diterapkan karena memiliki hubungan dengan kemampuan berpikir kritis siswa". Beda nya dengan penelitian yang penulis lakukan terletak pada hasil perhitungannya hasil perhitungan penulis menunjukkan hubungan yang 
positif dan tinggi sedangkan dalam jurnal menunjukkan hasil yang sebaliknya.

Hasil analisis data penelitian melalui perhitungan uji regresi untuk melihat Pengaruh kemampuan membaca,dan kedisiplinan belajar terhadap kemandirian belajar PAI siswa yang memilikiHasil perhitungan analisis regresi linear berganda didapatkan persamaan regresi yaitu $\mathbf{Y}=$ $\mathbf{1 2 . 8 6 5 + 0 , 2 2 4 X 1 + 0 , 7 2 0 \times 2 + e . P e r s a m a a n ~ i n i ~ b e r m a k n a ~ J i k a ~ v a r i a b e l ~}$ kemampuan membaca $\left(X_{1}\right)$, dan kedisiplinan belajar $\left(X_{3}\right)$ bernilai nol, maka kemandirian belajar PAI siswa ( Y) akan tetap sebesar12.865.Kemudian Jika variabel kemampuan membaca $\left(\mathrm{X}_{1}\right)$ Meningkat 1 (satu) persen sementara variabel kedisiplinan belajar $\left(X_{3}\right)$ di anggap tetap maka kemandirian belajar PAI siswa ( Y) akanmeningkat sebesar 0,224 persen. SertaJika variabel kedisiplinan belajar $\left(X_{3}\right)$ Meningkat 1 (satu) persen sementara kemampuan membaca $\left(X_{1}\right)$ di anggap tetap, di anggap tetap maka kemandirian belajar PAI siswa (Y) akan meningkat sebesar 0,720 persen.Kedua koefisien bernilai positif yang menyatakan bahwa ada pengaruh positif antara pengaruh kemampuan membaca $\left(X_{1}\right)$, dan kedisiplinan belajar $\left(X_{3}\right)$ terhadap kemandirian belajar PAI siswa (Y) kelas IX SMP Negeri 3 Perbaungan. Berdasarkan penjabaran tersebut dapat dijelaskan bahwa jika variabel-variabel bebas $\left(X_{1}, X_{3}\right)$ meningkat maka akan mempengaruhi peningkatan variabel terikat $Y$.

Penjelasan tersebut menyatakan bahwa secara simultan terdapat pengaruh yang positif dan signifikan antara kemampuan membaca dan kedisiplinan terhadap kemandirian belajar. yang di pertegas oleh intan Febriyanti Winoto (2014) dalam penelitiannya yang berjudul pengaruh disiplin belajar terhadap kemandirian belajar siswa kelas V SDN 03 Brujul Kecamatan Jaten Kabupaten Karanganyar tahun ajaran 2014/2015. hasil analisis menunjukkan bahwa disiplin belajar berpengaruh terhadap kemandirian belajar siswa. hal tersebut terbukti dari hasil koefisien arah regresi dari variabel disiplin belajar (b) adalah sebesar 0,615. dan dengan uji keberartian koefisien arah regresi sederhana untuk variabel disiplin belajar (b) diperoleh >yaitu 9,072 > 2,052 pada taraf signifikansi 5\%.

Hasil analisis data penelitian melalui perhitungan uji regresi untuk melihat Pengaruh kemampuan membaca,kemampuan berfikir kritis dan kedisiplinan belajar terhadap kemandirian belajar PAI siswa yang memilikiHasil perhitungan analisis regresi linear berganda didapatkan persamaan regresi yaitu $\mathbf{Y}=\mathbf{1 5 . 6 7 1}+0,312 \mathrm{X} 1+0,594 \mathrm{X} 2+$ e. Persamaan bermakna bahwaJika variabel kemampuan berfikir kritis $\left(X_{2}\right)$, dan kedisiplinan belajar $\left(\mathrm{X}_{3}\right)$ bernilai nol, maka kemandirian belajar PAI siswa 
( Y) akan tetap sebesar15.671.danJika variabel kemampuan berfikir kritis $\left(X_{2}\right)$ Meningkat 1 (satu) persen sementara variabel kedisiplinan belajar $\left(\mathrm{X}_{3}\right)$ di anggap tetap maka kemandirian belajar PAI siswa ( Y) akanmeningkat sebesar 0, 312 persen.Serta Jika variabel kedisiplinan belajar $\left(\mathrm{X}_{3}\right)$ Meningkat 1 (satu) persen sementara kemampuan berfikir kritis $\left(\mathrm{X}_{2}\right)$ di anggap tetap maka kemandirian belajar PAI siswa $(\mathrm{Y})$ akan meningkat sebesar 0,594 persen.Kedua koefisien bernilai positif yang menyatakan bahwa ada pengaruh positif antara pengaruh kemampuan berfikir kritis $\left(\mathrm{X}_{2}\right)$ dan kedisiplinan belajar $\left(\mathrm{X}_{3}\right)$ terhadap kemandirian belajar PAI siswa (Y) kelas IX SMP Negeri 3 Perbaungan. Berdasarkan penjabaran tersebut dapat dijelaskan bawa jika variabel-variabel bebas $\left(\mathrm{X}_{2}, \mathrm{X}_{3}\right)$ meningkat maka akan mempengaruhi peningkatan variabel terikat $\mathrm{Y}$.

Pernyataan hasil penelitian ini dipertegas oleh Yulia Slamet Setyaningtias (2018) dalam penelitiannya yang berjudul Pengaruh Tingkat Berpikir Kritis dan Kedisiplinan Belajar Terhadap Hasil Belajar Matematika Siswa Kelas X SMK. Hasil penelitian dengan tingkat signifikansi 5\% adalah (1) terdapat perbedaan pengaruh tingkat berpikir kritis terhadap hasil belajar matematika siswa, (2) terdapatperbedaan pengaruh kedisiplinan belajar terhadap hasil belajar matematikasiswa, dan (3) tidak terdapatpengaruh interaksi antaratingkat berpikir Kritisdan kedisiplinan belajar terhadap hasil belajar matematika siswa.

Hasil analisis data penelitian melalui perhitungan uji regresi untuk melihat Pengaruh kemampuan membaca,kemampuan berfikir kritis dan kedisiplinan belajar terhadap kemandirian belajar PAI siswa yang memilikiHasil perhitungan analisis regresi linear berganda didapatkan persamaan regresi yaitu $\mathrm{Y}=\mathbf{1 1 . 3 0 2}+\mathbf{0 , 1 7 3 X 1}+\mathbf{0 ,} 276 \mathrm{X} 2+0,524 \mathrm{X} 3+\mathrm{e}$. Persamaan ini menggambarkan apabila Jika variabel kemampuan membaca $\left(X_{1}\right)$, kemampuan berfikir kritis $\left(X_{2}\right)$ dan kedisiplinan belajar $\left(X_{3}\right)$ bernilai nol, maka kemandirian belajar PAI siswa $(Y)$ akan tetap sebesar 11.302. Jika variabel variabel kemampuan membaca $\left(X_{1}\right)$ Meningkat 1 (satu) persen sementara variabel kemampuan berfikir $\operatorname{kritis}\left(X_{2}\right)$ di anggap tetap, dan kedisiplinan belajar $\left(X_{3}\right)$ di anggap tetap maka akan kemandirian belajar PAI siswa ( $\mathrm{Y}$ ) sebesar 0,173 persen. Jika variabel kemampuan berfikir kritis $\left(X_{2}\right)$ Meningkat 1 (satu) persen sementara kemampuan membaca $\left(X_{1}\right)$ di anggap tetap, dan kedisiplinan belajar $\left(X_{3}\right)$ di anggap tetap maka kemandirian belajar PAI siswa (Y) sebesar 0,276 persen. Dan Jika variabel Kedisiplinan Belajar $\left(X_{3}\right)$ Meningkat 1 (satu) persen sementara Kemampuan Membaca $\left(X_{1}\right)$ di anggap tetap, dan 
Kemampuan Berfikir Kritis $\left(\mathrm{X}_{2}\right)$ di anggap tetap maka akan Kemandirian Belajar PAI siswa (Y) sebesar 0,524 persen.Kedua koefisien bernilai positif yang menyatakan bahwa ada pengaruh positif antara pengaruh kemampuan membaca $\left(X_{1}\right)$, kemampuan berfikir $\operatorname{kritis}\left(X_{2}\right)$ dan kedisiplinan belajar $\left(\mathrm{X}_{3}\right)$ terhadap kemandirian belajar PAI siswa $(\mathrm{Y})$ kelas IX SMP Negeri 3 Perbaungan. Berdasarkan penjabaran tersebut dapat dijelaskan bawa jika variabel-variabel bebas $\left(X_{1}, X_{2}, X_{3}\right)$ meningkat maka akan mempengaruhi peningkatan variabel terikat $Y$.

Selanjutnya, untuk melihat pengaruh juga dilakukan dengan melihat hasil analisis hipotesis Secara simultan, nilai $f_{\text {hitung }}>f_{\text {tabel }}$ dimana $237.611>2,77$. Hal ini berarti bahwa secara simultan atau bersama-saam ada pengaruh signifikan antara kemampuan membaca, kemampuan berfikir kritis dan kedisiplinan belajar terhadap kemandirian belajar PAI siswa kelas IX SMP Negeri 3 Perbaungan.

Hasil analisis Nilai koefisien determinasi dalam penelitian ini adalah nilai $R$ Square sebesar 0,963. Besarnya nilai koefisien 0,963 sama dengan 96,30\%. Nilai tersebut berarti bahwa sebesar 96,30\% kemandirian belajar PAI siswa kelas IX SMP Negeri 3 Perbaungan. dapat dijelaskan melalui variabel kemampuan membaca, kemampuan berfikir kritis dan kedisiplinan belajar. Sebesar 3,70\% sisanya dipengaruhi oleh variabel lain yang tidak disertakan dalam penelitian ini. Dan dengan taraf signifikansi $5 \%$.

Hasil analisis menunjukkan bahwa terdapat pengaruh yang positif dan signifikan antara kemampuan membaca, kemampuan berfikir kritis dan kedisiplinan terhadap kemandirian belajar siswa. Hasil penelitian ini menjawab semua hipotesis yang ada dan membuktikan kebenaran dari teori-teori yang digunakan dalam penelitian ini yang dibuktikan dengan Besarnya nilai koefisien 0,963 sama dengan 96,30\%. Nilai tersebut berarti bahwa sebesar $96,30 \%$ ketiga variabel bebas tersebut secara bersama-sama dapat mempengaruhi kemandirian belajar.

\section{SIMPULAN}

Simpulan yang dapat ditarik dari hasil penelitian adalah: (1) ada hubungan positif dan signifikan antara kemampuan membaca terhadap Kemandirian belajar siswa pada mata pelajaran PAI kelas IX SMP Negeri 3 Perbaungan T.A2017/2018yang dibuktikan dengan $t_{\text {hitung }}>t_{\text {tabel }}$ dimana 2,992 >2,003, (2) ada hubungan positif dan signifikan antara kemampuan berfikir kritis terhadap Kemandirian belajar siswa pada mata pelajaran PAI kelas IX SMP Negeri 3 Perbaungan T.A2017/2018yang dibuktikan 
dengan hasil perhitungant $t_{\text {hitung }}>t_{\text {tabel }}$ dimana $4.553>2.003$, (3) ada hubungan positif dan signifikan antara kedisplinan belajar terhadap Kemandirian belajar siswa pada mata pelajaran PAI kelas IX SMP Negeri 3 Perbaungan T.A2017/2018yang dibuktikan dengan hasil perhitungan $t_{\text {hitung }}>t_{\text {tabel }}$ dimana $8.353>2.003$, (4) ada pengaruh yang positif dan signifikan kemampuan membaca, dan kemampuan berfikir kritis, terhadap Kemandirian belajar siswa pada mata pelajaran PAI kelas IX SMP Negeri 3 Perbaungan T.A2017/2018yang dibuktikan dengan hasil perhitungan $\mathrm{Y}=15.238+0,352 \mathrm{X} 1+0,623 \mathrm{X} 2+\mathrm{e}$, (5) ada pengaruh yang positif dan signifikan kemampuan membaca, dan kedisplinan belajar terhadap Kemandirian belajar siswa pada mata pelajaran PAI kelas IX SMP Negeri 3 Perbaungan T.A2017/2018yang dibuktikan dengan hasil perhitungan $\mathrm{Y}=12.865+0,224 \mathrm{X} 1+0,720 \mathrm{X} 2+\mathrm{e},(5)$ ada pengaruh yang positif dan signifikan kemampuan berfikir kritis, dan kedisplinan belajar terhadap Kemandirian belajar siswa pada mata pelajaran PAI kelas IX SMP Negeri 3 Perbaungan T.A2017/2018yang dibuktikan dengan hasil perhitungan $\mathrm{Y}=15.671+0,312 \mathrm{X} 1+0,594 \mathrm{X} 2+\mathrm{e}$, dan (6) ada pengaruh yang positif dan signifikan kemampuan membaca, kemampuan berfikir kritis, dan kedisplinan belajar terhadap Kemandirian belajar siswa pada mata pelajaran PAI kelas IX SMP Negeri 3 Perbaungan T.A2017/2018 yang dibuktikan dengan $F_{\text {hitung }}>F_{\text {tabel }}$ dimana $F_{\text {hitung }} 237.611>F_{\text {tabel }} 2,77$.

\section{DAFTAR PUSTAKA}

Al-Maragi Ahmad Mustafa, (1993). Tafsir Al Maragi Juz IV. Semarang: Karya Toha Putra

Amri sofan. (2013). Pengembangan dan Model Pembelajaran dalam Kurikulum 2013". Jakarta: Prestasi Pustakarya.

Arikunto,Suharsimi. (2013). "Prosedur Penelitian suatu pendekatan praktek". Jakarta: Rieka Cipta.

Asrori,Mohammad. (2007)."Psikologi Pembelajaran".Bandung: Wacana Prima.

Henry Guntur Tarigan. (2005)."Mebaca Sebagai Suatu Keterampilan Berbahasa".Bandung: Angkasa.

Hamalik,Oemar. (2010) . Proses Belajar Mengajar.Jakarta: Bumi Akasara.

Hamid,Hamadi. (2013). Pengembangan Sistem Pendidikan Di Indonesia. Bandung:Pustaka Setia.

Istarani \& Pulungan, Intan. (2015) .Ensiklopedi Pendidikan Jilid I.Medan:MediaPersada. 
M. Hasbi Ash-Shiddieqy, (1987) Sejarah dan Pengantar Ilmu Al-Qur'an atau Tafsir, Jakarta: Bulan Bintang.

Mohamad Surya . 2015. "Strategi Kognitif dalam Proses Pembelajaran"Bandung. Alfabeta.

Mulyasa. (2004). Kurikulum Berbasis Kompetensi. Bandung: Remaja Rosdakarya.

Pandiangan,L. (2012). “Pengaruh Strategi Pembelajaran Berbasis Masalah dan Kemandirian Belajar terhadap Hasil Belajar Pkn di SMP Hinai”. Tesis: Medan. Universitas Negeri Medan.

Rusydi Ananda dan Muhammad Fadli. (2018) Statistik Pendidikan. Teori dan Praktek Dalam Pendidikan. Medan, Widya Puspita.

ShihabM. Quraisy, (2002).Tafsir Al-Mishbah. Jakarta: Lentera Hati.

Slameto. (2010). Belajar dan Faktor - Faktor Yang Mempengaruhinya. Jakarta: Rineka Cipta.

Sugiyono. (2017)."Metode Penelitian Pendidikan".Bandung:Alfabeta.

Tampubolon. (2016)."Kemampuan Membaca Teknik Membaca Efektif Dan Efisien".Bandung:Angkasa.

Tirtarahardja dan Sulo. (2008)."Pengantar Pendidikan".Jakarta:Rineka Cipta. Undang-Undang No. 20 Tahun 2003 tentang Sistem Pendidikan Nasional.

Walker, G.H. (2001). "Critical Thinking" walker centre for teaching and learning "http://www.Walker-centre-for-teaching-and-learning/faculty development. diakses 23 september 2017 